\title{
Performance Evaluation of Onion Varieties at Biyo Awale Cluster in Diredawa Administration
}

\author{
*Fikadu Tadesse Frezer Yemane Mohammed Jafar \\ Oromia Agricultural Research Institute, Fedis Agricultural research center, P.O.Box=904, Harar, Ethiopia
}

\begin{abstract}
Onion (Allium cepa L.) is an important crop worldwide. It is important in the daily Ethiopian diet. It is widely produced by small farmers and commercial growers throughout the year for local use and export market. No strong study has been conducted to evaluate the suitability of onion cultivation in Biyo Awale district of Diredawa. Hence, the present experiment was conducted to study the performance of improved varieties of onion for their suitability for cultivation in Biyo Awale district of Diredawa. The study was carried out during 20182019 cropping season to test the performance of onion varieties. Five high yielding onion varieties were planted in complete randomized block design experiment with three replications including local check at farmer's field. The quantitative data on bulb yield, plant height, bulb size and number of leaves of onion varieties were collected. Harvesting was done and weighed when all onion varieties reach maturity ( $90 \%$ tops down). The results revealed that the tested onion varieties differ significantly for leaf length, leaf number, neck diameter, bulb diameter, average bulb weight and bulb yield. Among the varieties Bombay red and Melkam produced higher bulb yield (25.56 and $21.13 \mathrm{t} \mathrm{ha}^{-1}$ ) and gave $140.68 \%$ and $98.96 \%$ yield advantage over local check varieties, respectively. Therefore, Bombay Red and Melkam varieties were recommended to the study area and similar agro-ecology.
\end{abstract}

Keywords: Bulb yield, Onion, Varieties

DOI: $10.7176 /$ ALST/90-01

Publication date: November $30^{\text {th }} 2021$

\section{Introduction}

Onion (Allium cepa L.), is an important vegetable belonging to family Alliaceae and widely grown herbaceous biennial vegetable crop with cross-pollinated and monocotyledonous behavior having diploid chromosomes number $2 \mathrm{n}=16$ (Bassett, 1986). The production of fruits and vegetables has a comparative advantage particularly under conditions where arable land is scarce, labor is abundant and markets are accessible (Lumpkin et al., 2005). The production of horticultural products offers opportunities for poverty alleviation, because it is usually more labor intensive than the production of staple food crops. Hence, the generation of additional employment opportunities in rural areas where labor is abundant is made possible. Increasing horticultural production contributes to commercialization of the rural economy and creates many off-farm jobs (Lumpkin et al., 2005). Vegetables took up about $0.98 \%$ of the area under all crops at national level. Onion cultivated on 31,673.21 ha with a total production of $2,938,875.85$ quintals (CSA, 2017). It is recently introduction and rapidly becoming popular among producers and consumers. It is widely produced by small farmers and commercial growers throughout the year for local use and export market. Onion is valued for its distinct pungency and form essential ingredients for flavoring varieties of dishes, sauces, soup, sandwiches, and snacks as onion rings. It is popular over the local shallot because of its high yield potential per unit area, availability of desirable cultivars for various uses, ease of propagation by seed, high domestic (bulb and seed) and export (bulb, cut flowers) markets in fresh and processed forms. The method of cultivation is via direct seeding or transplanting in the field growing. The weight of thousand seeds is about $3.6 \mathrm{~g}$ that can be produced by open Pollination via honey bees. Regarding seed production, it is necessary to plant maternal bulb in field in the due time. Otherwise, cold weather can influence seedlings which resulted in the induction of flowering. On the other hand, the proper time for planting maternal bulb is of value because of the optimum use of the land seed favorite production both quantitatively and qualitatively. Also, the bulb size is one of the most important factors in seed production (Nehra et al., 1988; Navab et al., 1998; Khodadadi, 2009). Therefore, planting bulbs with the proper diameter as well as high seed production, have been caused cost saving in the amount of consumption per hectare and, thus can be reduced the production cost (Basol et al., 1997).

Onion contributes substantially to the national economy, apart from overcoming local demands. Products like bulbs and cut flowers are exported to different countries of the world. Currently many farmers have changed their life in onion development program. With the growing irrigated agriculture in the country, there is a great potential for extensive onion seed and dry bulb in different production belt in the country. Unfortunately, some parts of the Diredawa ecology, particularly Biyo Awale cluster are unable to produce enough onion for local consumption due to non-availability of improved planting materials. The available local variety in production has low yield, with poor quality bulbs, short shelf life due to very high water content of the bulbs and high susceptibility to insect pest and diseases. However, the knowledge of the types of variety that will yield best in a 
given environment is important for good crop management decisions. Therefore, this paper was initiated with the objective to identify high yielding and disease tolerant variety of onion with a view of recommending it for Diredawa rural areas of Biyo Awale

\section{Materials and Methods}

\section{Description of the Study Area}

The experiment was conducted in Diredawa Administration Council at Adada and Bishan Baye village during the rainy season from early July to early November, 2017. Geographically, Diredawa Administration Council is located in the eastern part of Ethiopia between $9027^{\prime} \mathrm{N}$ and $9049^{\prime} \mathrm{N}$ latitude and $41038^{\circ} \mathrm{E}$ and $42019^{\circ} \mathrm{E}$ longitude. The mean annual temperature is about $24.8^{\circ} \mathrm{C}$ with a range of $31.4^{\circ} \mathrm{C}$ and $18.2^{\circ} \mathrm{C}$ average maximum and minimum temperatures, respectively. The rainfall pattern of the Administration has a bimodal characteristic. The small rainy season is from March to April; while the big rainy season extends from August to mid-September with average annual rainfall of the Administration is over $604 \mathrm{~mm}$ (Diredawa Administration Meteorological Station)

\section{Experimental material and Design}

Four improved varieties of onion introduced from Melkasa Agriculture Research Center, Melkam, Nafis, Bombay red, Adama red with local check collected from "Adada and Bishan baye" peasant associations were used in this study. The experiment was laid out in RCB design with three replications. The size of each experimental plot was $5.4 \mathrm{~m}^{2}$ ( $3 \mathrm{~m}$ wide and $1.8 \mathrm{~m}$ long). The onion varieties were randomly assigned to the experimental plots. The inter row spacing used was $20 \mathrm{~cm}$ for bulb. Seeds of each onion variety were sown in rows of $15 \mathrm{~cm}$ on well prepared seed bed of $1 \times 5 \mathrm{~m}$ and covered with light soil and mulching grasses until emergence. The beds were watered with watering can as supplementary irrigation. The seedlings were thinned at $3 \mathrm{~cm}$ spacing within rows, followed by proper weeding and watering. Land preparation was done in advance to reduce diseases and insect pest incidence. Finally, hardened, healthy and uniform seedlings of pencil size were transplanted at an age of 30 days (MoARD, 2009). The transplanted seedlings were watered and inorganic fertilizers (NPS) and urea was applied at the recommended rate. All the phosphate fertilizer were applied at transplanting whereas nitrogen was given at two equal splits (at transplanting and 30 days after transplanting) as basal application (EARO, 2004). Plots were irrigated when there is insufficient rainfall as supplementary irrigation. Weeding, cultivation, watering, staking, chemical spray etc. were done as recommended.

\section{Data collected}

Data of Bulb diameter, number of leaves per plant, leaf length, average weight of bulb, neck diameter, bulb yield, disease and insect pest were collected. Analysis of variance was carried out using GenStat discovery $15^{\text {th }}$ edition software for the parameters studied following the standard procedures outlined by Gomez and Gomez (1984).The means were separated using the Fisher's Protected Least Significant Difference (LSD) test at 5\% level of probability.

\section{Results and Discussions}

Analysis of variance (ANOVA) indicated that there was significance difference among onion varieties for leaf number, leaf length, Neck diameter, bulb diameter, average bulb weight and Bulb yield tested at 5\% probability level. However, no significance difference was observed between varieties for days to maturity and plant height. This might be due to genetic makeup and environment that agrees with findings of Jilani, M.S. and Ghafoor, A. (2003) reported that various cultivars of the same species grown in the same environment give different yields as the performance of a cultivar mainly depends on the interaction of genetic makeup and environment.

\section{Leaf Number, Leaf length and Neck Diameter}

Analysis of variance revealed that there was significance difference $(\mathrm{P}<0.05)$ among varieties for leaf number, leaf length and neck diameter (table 1). The highest leaf number (12.92) was recorded from Adama red variety, while the lowest $(8.54)$ from Nafis. On the other hand the highest leaf length $(40.02 \mathrm{~cm})$ was recorded from Melkam varieties while the lowest $(34.68 \mathrm{~cm})$ from Nafis variety. The result also showed the highest neck diameter $(1.72 \mathrm{~cm})$ gained from Nafis while the lowest $(0.94 \mathrm{~cm})$ was from Bombay red variety.

\section{Bulb Diameter and Average Bulb weight}

Analysis of variance revealed that there was significance difference $(\mathrm{P}<0.05)$ among varieties for bulb diameter and average bulb weight (Table 1). The bulb diameter was range between 5.99 and $4.75 \mathrm{~cm}$. The highest bulb diameter was recorded from Melkam (5.99) while the lowest was from Nafis $(4.75 \mathrm{~cm})$. The current result also revealed the highest average bulb weight $(92.79 \mathrm{~g})$ was from Bombay red while the lowest (42 g) was from local cultivar. 
Table: 1 The Mean of growth, yield and yield parameters for the onion varieties.

\begin{tabular}{lllllllll}
\hline Variety & DM & PH $(\mathrm{cm})$ & LN & LL $(\mathrm{cm})$ & ND $(\mathrm{cm})$ & BD $(\mathrm{cm})$ & ABW $(\mathrm{g})$ & $\mathrm{BY}(\mathrm{t} / \mathrm{ha})$ \\
\hline Bombay red & 137.2 & 45.56 & $11.08^{\mathrm{ab}}$ & $39.19^{\mathrm{a}}$ & $0.94^{\mathrm{d}}$ & $5.863^{\mathrm{a}}$ & $92.79^{\mathrm{a}}$ & $25.56^{\mathrm{a}}$ \\
Adama red & 135.2 & 51.08 & $12.92^{\mathrm{a}}$ & $38.63^{\mathrm{ab}}$ & $1.69^{\mathrm{ab}}$ & $5.48^{\mathrm{a}}$ & $76.34^{\mathrm{b}}$ & $16.32^{\mathrm{bc}}$ \\
Melkam & 134.2 & 48.84 & $10.92^{\mathrm{ab}}$ & $40.02^{\mathrm{a}}$ & $1.45^{\mathrm{bc}}$ & $5.99^{\mathrm{a}}$ & $91.46^{\mathrm{a}}$ & $21.13^{\mathrm{ab}}$ \\
Nafis & 137.2 & 45.27 & $8.54^{\mathrm{b}}$ & $34.68^{\mathrm{b}}$ & $1.72^{\mathrm{a}}$ & $4.75^{\mathrm{b}}$ & $70.15^{\mathrm{b}}$ & $13.23^{\mathrm{c}}$ \\
Local & 139.5 & 49.43 & $9.54^{\mathrm{ab}}$ & $37.30^{\mathrm{ab}}$ & $1.38^{\mathrm{c}}$ & $4.847^{\mathrm{b}}$ & $42^{\mathrm{c}}$ & $10.62^{\mathrm{c}}$ \\
\hline LSD $(0.05)$ & $\mathrm{NS}$ & $\mathrm{NS}$ & 4.52 & 5.577 & 0.3581 & 0.8763 & 12.1 & 7.85 \\
CV $(\%)$ & 3.4 & 14.5 & 24.9 & 8.6 & 14.6 & 9.5 & 9.5 & 26.4 \\
\hline
\end{tabular}

N.B. Means within the same column followed by the same letter (s) are not significantly different at $5 \%$ level of significance; $\mathrm{DM}=$ Days to maturity, $\mathrm{PH}=$ plant height, $\mathrm{LN}=$ Leaf Number, LL=Leaf Length, ND=Neck Diameter, $\mathrm{BD}=$ Bulb Diameter, $\mathrm{ABW}=$ Average Bulb Weight, BY=Bulb Yield; LSD=Least Significant Difference; $\mathrm{NS}=$ Not significant; $\mathrm{CV}=$ Coefficient of variation

\section{Bulb yield}

Analysis of variance revealed that there was significance difference $(\mathrm{P}<0.05)$ among varieties for bulb yield (Table 1). The bulb yield ranged from $25.56 \mathrm{t} \mathrm{ha}^{-1}$ to $10.62 \mathrm{t} \mathrm{ha}^{-1}$. The highest bulb yield $\left(25.56 \mathrm{t} \mathrm{ha}^{-1}\right)$ was obtained from Bombay red variety followed by the varieties Melkam (21.13 $\left.\mathrm{t} \mathrm{ha}^{-1}\right)$, Adama red $\left(16.32 \mathrm{t} \mathrm{ha}^{-1}\right)$ and Nafis $\left(13.23 \mathrm{t} \mathrm{ha}^{-1}\right)$ while the lowest yield $\left(10.62 \mathrm{t} \mathrm{ha}^{-1}\right)$ was obtained from local check. Bombay red and Melkam gave $140.68 \%$ and $98.96 \%$ yield advantage over local check respectively. Statistically, significance difference was not observed among Adama red, Nafis and local check for bulb yield. The variation in bulb yield of the tested varieties showed the difference in adaptability of these varieties to the study areas. The highly performed varieties revealed that the most adaptability to this environment. These results are in agreement with the findings of (Jilani and Ghofer, 2003, Kimani et al, 1993) reported that various cultivars of the same species grown in the same environment give different yields as the performance of a cultivar mainly depends on the interaction of genetic makeup and environment. These results are disagree with the findings of (Mitiku et al, 2017) It implies that the onion varieties do not responded to the climatic conditions and reflected non-significantly to their productivity performance.

\section{Conclusion and Recommendation}

After conducting for two consecutive years in the Diredawa, Biyo Awale area, varieties showed significant difference for leaf number, leaf length, neck diameter, bulb diameter, average bulb weight and bulb yield. Accordingly Bombay red gaves the highest average bulb weight and bulb yield followed by Melkam as compared to local check and other varieties. Furthermore, Bombay red and Melkam varieties showed 140.68\% and $98.96 \%$ yield advantage over the local check, respectively. Therefore, Bombay red and Melkam varieties were recommended to the study area and similar agro-ecologies.

\section{Acknowledgement}

The authors would like to thank the Oromia Agricultural Research Institute (OARI), Fedis Agricultural Research Center (FARC) and AGP-II for financing and providing working facility of the study. Moreover, we acknowledge Mr. Murtesa Yusuf for his involvements in field data collection. Great thanks also go to Mr. Hassen Umare who provided experimental land for the success of this research experiment.

\section{Reference}

Basol L, Ram L, Pandey U B. (1997). Effects of onion size and storing method one seed yield and some agronomical factors of onion (Allium cepa L.). Seed Res., 13(3): 68-80.

Bassett, M.J. 1986. Breeding Vegetable Crops. AVI Publishing Co. Inc. West Port. Connecticut. 584p.

Central Statistical Agency, (2017). Agricultural Sample Survey Report on Area and Production of Major Crops Private Peasant Holdings, Meher Season.

Jilani, M.S. and Ghafoor, A. (2003). Screening of Local Onion Varieties for Bulb Formation. International Journal of Agriculture and Biology, 5 (2), 129-133.

Khodadadi M. (2009). Effects of maternal bulb size, plant density and planting date on the yield and yield components of onion Ghole Ghese variety. Abhar Islamic Azad University Pub., Iran, 28 pp.

Kimani, P.M., Kariuki, J.W., Peters, R. and Rabinowitch, H.D. (1993). Influence of the Environment on the Performance of Some Onion Cultivars in Kenya. African Crop Science journal, 1(1), 15 -23.

Lumpkin, T.A., Weinberger, K., and Mooree, S. (2005). Increasing Income through Fruits and Vegetable Production, Opportunities and Challenges.Marrakech, Morocco.

Misgana Mitiku, and Awoke Tadesse. (2017). “Adaptability Study of Improved Onion (Allium Cepa L.)Varieties at South Ari Woreda of South Omo Zone, Ethiopia.”International Journal of Research-Granthaalayah, 5(7), 
$541-545$

Navab A, Baloch MA, Hussain SA, Ali N. (1998). Study on the effects of planting space and bulb size on seed production in onion crop. Sarhad Journal of Agriculture. 14: 6,563-568.

Nehra B K, Pandita M L, Singh K. (1988). Effect of bulb size, spacing and nitrogen on plant growth and seed yield. Hort. Abstr., 62(10). 